\title{
Invasive toads are close to but absent from Komodo National Park
}

\author{
Umar F Kennedi ${ }^{1 *}$, Mirza D Kusrini ${ }^{1}$, Achmad Ariefiandy ${ }^{2}$, and Ani Mardiastuti ${ }^{1}$ \\ ${ }^{1}$ Departement of Conservation of Forest resources and Ecotourism, Faculty of Forestry, IPB University, Bogor, Indonesia \\ ${ }^{2}$ Komodo Survival Program, Bali, Indonesia
}

\begin{abstract}
The islands of Komodo National Park in the Wallacea region are the habitats of Komodo dragon (Varanus komodoensis). Although the Wallacea islands have lower species richness compared to the other large islands in Indonesia, they are rich in endemics, and the occurrence of invasive species would therefore threatened the ecological, economic and social balance of the regions. Several papers have hinted at the possibility of the invasion of Komodo National Parks by Asian toads, a situation which would potentially affect the survival of the Komodo dragon. To detect the presence of the invansive toad Duttaphrynus melanostictus in Komodo National Park and its surroundings areas we carried out an amphibian survey using a Visual Encounter Survey method during February to April 2018. The surveyed location consisted of two main islands within Komodo National Park (Rinca island and Komodo island), Flores island (Labuan Bajo and Cumbi village) and Sumbawa island (Sape). Two species of amphibians were found in Komodo National Park (Rinca island and Komodo island), while seven species of amphibians were found across all four locations. No D. melanostictus toads were found in Flores (including in Komodo National Park), however the toad was found to be abundant in Sape (Sumbawa island).
\end{abstract}

\section{Introduction}

One of the threats to the existence of endemic species is the presence of invasive species. This has become a global problem because of its impact on ecosystems and the high costs to mitigate the negative impacts [1-3]. The Asian common toad (Duttaphrynus melanostictus) is a widely distributed toad in Asia. The species occurs in Indonesia, mostly in Sundaland but has been known to have invaded the Wallacea region over the last 50 years as a result of human activities [4]. Duttaphrynus melanostictus belongs to the Bufonidae, which many members of this family have paratoid glands that secrete toxic substance to predators such as birds, lizards, crocodiles, snakes and mammals [5]. One of the notable species of this family is the cane toad Rhinella marina, which in Australia has caused the death of freshwater crocodiles (Crocodylus johnstoni) and significant population decline in Varanus mertensi [6].

The spread of D. melanostictus from Java to Bali had been reported by the end of 1950's [7], and reports of many sightings showed that the species had later spread to other neighbouring islands [8]. There is no known impact of this species on the endemic species in Indonesia, however, there is a concern about the impact of the toad elsewhere, for example into Madagascar [9]. There is a concern that the toad might become invasive in the Komodo National Park and potentially cause negative impacts on the population of Komodo dragon Varanus komodoensis [4]. Komodo National Park consist of five main islands (Komodo, Rinca, Nusa Kode, Gili Motang and Padar) and 126 smaller islands. Those five main islands are the home of the famous Komodo dragon $V$. komodoensis. The possible existence of D. melanostictus in Komodo National Park therefore needs to be investigated as a basis for the management of the park, with a view to minimising the possible impacts of the toad on conservation of the Komodo dragon. This paper reports a survey of amphibian species richness in Komodo National Park and its surrounding area (Sape on Sumbawa island and Labuan Bajo and Cumbi village on Flores island) with the aim to detecting the presence of the Asian common toad D. melanostictus in the area.

\section{Methods}

Data were collected at nine locations across four islands: Sumbawa island (Sape), Komodo island (Komodo village, Loh Liang, and Loh Wau), Rinca island (Rinca village, Loh Buaya and Loh Baru) and Flores island (Labuan Bajo and Cumbi Village). The chosen locations encompass residential and forested areas, since $D$. melanostictus is mostly found in human habitats such as

\footnotetext{
* Corresponding author: fhadli kennedi@apps.ipb.ac.id
} 
settlements, gardens, plantations and ditches [10]. The survey area was mainly valleys with elevations of between 2 and $270 \mathrm{~m}$, which were mostly dry and arid. The rainy season usually only occurs from January to March [11]. In Komodo, freshwater sources were present in Komodo village and Loh Wau from the streams that flows throughout the year while in Loh Liang there were no permanent water sources and the stream there only flows during the rainy season. All locations in Rinca have water all year round. Labuan Bajo and Cumbi village (Flores island) are also considered dry, however they are relatively wetter than Komodo National Park and water sources are plentiful and flows throughout the years. Similarly, Sape in the eastern part of Sumbawa is comparatively wet, with water that flows all year round. Sape and Labuan Bajo are the main entry points to enter Komodo National Park.

Data were collected at the end of the rainy season, during February to April 2018. We concentrated the survey on areas within a maximum range of $100 \mathrm{~m}$ from water sources to ensure that we were able to observe amphibians. Visual encounter survey method [12] were carried out by two or three surveyors randomly walking through the selected habitat. We actively searched the areas at night (19:00-21:00 Eastern Indonesian Time), looking at the forest floor, leaf litter, fallen logs, water bodies, and surrounding vegetation. Total effort during the research was 654 man-hours. The occurrence of a species was determined by the finding of both its adult and juvenile forms.

We recorded locations, species, date of capture, sex (if possible), microhabitat, behaviour of each individual, substrates, and also measurements of environmental conditions (water, air and substrate temperatures, and humidity) at the time of capture. Habitat characteristic are noted. Frogs were released after examination at the point of capture, except for a small number that were caught and preserved with $90 \%$ alcohol as voucher specimens, especially for species which had not been identified. Voucher specimens are stored at Museum Zoologicum Bogoriense. Nomenclature follows reptile database [13] and amphibian database from American Museum Natural History (AMNH) [8].

We measured body size (snout vent length or SVL) and only reported the result for the most abundant species. D. melanostictus found during field work were measured and weighed and grouped into adolescent, male and female categories [14]. We checked specimens at Museum Zoologicum Bogoriense Cibinong to record the distribution of $D$. melanostictus in Nusa Tenggara (Lesser Sunda) and the existence of the Asian toad ( $D$. melanostictus) was mapped using ArcGIS 10.5 based on the results of research and literature studies.

\section{Result and Discussions}

We recorded seven species of amphibians from four families, but only found two species of amphibians in Komodo National Park: Fejervarya cancrivora and Kaloula baleata (Table 1). A report from Auffenberg [16] showed that amphibian communities in Komodo island were very scarce, listing only two species: $O$. jeffersoniana and Kaloula baleata. Auffenberg's records were based of almost three years of fieldwork during the periods of 1969-1970, 1971 and 1973 which included both rain and dry seasons, thus increasing the opportunity of identifying more species. There is no existing report on amphibian on the island of Rinca and Padar. The low amphibian richness in these islands is understandable due to the fact that the islands of Komodo National Park are mostly small and dry. Based on the biogeographic theory of MacArthur \& Wilson [15], the number of species on an island is influenced by the size of the island and the distance to the mainland, aspect which affect both rate of extinction and immigration. This theory suggests that Flores and Sumbawa, which are large (main) islands, should have greater species diversity than Rinca and Komodo islands, and this is confirmed by the result of this study.

Table 1. Relative abundance (individual/man-hours) of amphibian at Komodo National Park and its surrounding areas based on islands

\begin{tabular}{|c|c|c|c|c|}
\hline $\begin{array}{c}\text { Scientific } \\
\text { Name }\end{array}$ & $\begin{array}{c}\text { Komodo } \\
\text { Island }\end{array}$ & $\begin{array}{c}\text { Rinca } \\
\text { Island }\end{array}$ & $\begin{array}{c}\text { Labuan } \\
\text { Bajo } \\
\text { (Flores) }\end{array}$ & $\begin{array}{c}\text { Sape } \\
\text { (Sumbawa) }\end{array}$ \\
\hline $\begin{array}{c}\text { Fejervarya } \\
\text { cancrivora }\end{array}$ & - & 12.12 & 66.67 & 81.48 \\
\hline $\begin{array}{c}\text { Fejervarya } \\
\text { limnocharis }\end{array}$ & - & - & 4.00 & 9.26 \\
\hline $\begin{array}{c}\text { Limnonectes } \\
\text { kadarsani }\end{array}$ & - & - & 21.33 & - \\
\hline $\begin{array}{c}\text { Kaloula } \\
\text { baleata }\end{array}$ & 0.36 & 1.21 & 18.67 & 3.70 \\
\hline $\begin{array}{c}\text { Oreophryne } \\
\text { jeffersoniana }\end{array}$ & - & - & 5.33 & - \\
\hline $\begin{array}{c}\text { Duttaphrynus } \\
\text { melanostictus }\end{array}$ & - & - & - & 114.81 \\
\hline $\begin{array}{c}\text { Polypedates } \\
\text { leucomystax }\end{array}$ & - & - & 4.00 & 5.56 \\
\hline
\end{tabular}

Auffenberg [16] noted that $O$. jeffersoniana was found in moist upland forest areas while K. baleata was found in drier savannah areas. Despite effort to find $O$. jeffersoniana in the wet region of the forested area of Komodo (Loh Wau) we did not find any specimens. The typical locality of this frog on Komodo Island is in the upper elevation $(600 \mathrm{~m})$ [17], however the single specimen identified by Auffenberg was found in low land (below $100 \mathrm{~m}$ ) similar to our survey location. It is possible that $O$. jeffersoniana might have disappeared from Komodo as there are no reported sightings of this species after Auffenberg [16], or it may still persist in upper elevations which has not been visited since Auffenberg's study 50 years ago. The finding of $K$. baleata in Komodo village (on Komodo island) and also in Loh Buaya and Loh Baru (Rinca island) shows that this frog is able to exist in these areas.

The other amphibian found in Komodo National Park was Fejervarya cancrivora which we found in abundance only in Rinca (at Loh Buaya and Loh Baru). The frog was found in three locations and is the most abundant amphibian on Rinca and Flores. It is well known that these $F$. cancrivora are widespread in 
Indonesia and other southeast Asian countries, and that they can adapt well to human-made habitats [8, 10, 18]. It is not clear if $F$. cancrivora has been established in Rinca for a long time or is a recent immigrant.

There is a significant difference between mean SVL of $F$. cancrivora in Flores $(\mathrm{M}=4.45 \mathrm{~cm}, \mathrm{SD}=1.06)$ and Rinca $\left(\mathrm{M}=3.70 \mathrm{~cm}, \mathrm{SD}=1.13 ; \mathrm{t}_{75}=2,869, \mathrm{P}=0.005\right)$; however, there is no significant differences between Rinca and Sumbawa $\left(\mathrm{M}=4.37 \mathrm{~cm}, \mathrm{SD}=1.16 ; \mathrm{t}_{44}=\right.$ $1.945, \mathrm{P}=0.058)$ and between Sumbawa and Flores $\left(\mathrm{t}_{67} \backslash\right.$ $=-0.274, \mathrm{P}=0.785)$. Based on mass, there is no significant differences between mean mass of $F$. cancrivora in Sumbawa $(\mathrm{M}=5.37 \mathrm{~g}, \mathrm{SD}=1.85)$ with Rinca $\left(M=5.20 \mathrm{~g}, \mathrm{SD}=3.49 ; \mathrm{t}_{46}=0.195, \mathrm{P}=0.846\right)$, between Rinca and Flores $\left(\mathrm{M}=7.03 \mathrm{~g}, \mathrm{SD}=3.73 ; \mathrm{t}_{77}=\right.$ $2,15, \mathrm{P}=0.035)$ and between Sumbawa and Flores $\left(\mathrm{t}_{46}=\right.$ $0.195, \mathrm{P}=0.846$ ) (Table 2).

Table 2. Mean size (Snout Vent Length), Weight and number of Fejervarya cancrivora in Rinca, Labuan Bajo (Flores) and Sape (Sumbawa)

\begin{tabular}{|c|c|c|c|c|c|c|c|}
\hline \multirow{2}{*}{ 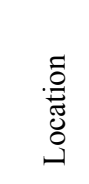 } & \multirow[b]{2}{*}{$\mathrm{N}$} & \multicolumn{3}{|c|}{ SVL (cm) } & \multicolumn{3}{|c|}{ W (g) } \\
\hline & & $\Xi$ & $\sum^{\stackrel{㐅}{\Sigma}}$ & 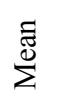 & $\stackrel{\Xi}{\Xi}$ & $\sum_{\Sigma}^{\check{\Xi}}$ & $\sum^{\Xi}$ \\
\hline Rinca & 30 & 2.1 & 7.0 & $\begin{array}{c}3.70 \\
\pm \\
1.13 \\
\end{array}$ & 1.5 & 16.5 & $\begin{array}{c}5.20 \\
\pm \\
3.49 \\
\end{array}$ \\
\hline $\begin{array}{c}\text { Labua } \\
\text { n Bajo } \\
\text { (Flore } \\
\text { s) }\end{array}$ & 50 & 3.0 & 8.0 & $\begin{array}{c}4.45 \\
\pm \\
1.06 \\
\end{array}$ & 3.5 & 22.0 & $\begin{array}{c}7.03 \\
\pm \\
3.73 \\
\end{array}$ \\
\hline $\begin{array}{c}\text { Sape } \\
\text { (Sumb } \\
\text { awa) }\end{array}$ & 44 & 1.5 & 6.1 & $\begin{array}{c}4.37 \\
\pm \\
1.16\end{array}$ & 0.5 & 8.0 & $\begin{array}{c}5.37 \\
\pm \\
1.85\end{array}$ \\
\hline
\end{tabular}

The Asian common toad D. melanostictus was only found in Sape (Fig. 2), Sumbawa where it is the most abundant species in the location. Almost half of the specimens were mostly found in human settlements $(n=33)$. Compared to other species in the survey, it had the highest relative abundance (114.81 ind/man-hours), whereas the lowest relative abundance was for $K$. baleata in Komodo island (0.36 ind/man-hours) (Table 1). The toads were found in both adult and juvenile stages (Table 3). Data from Museum Zoologicum Bogoriense has shown that the earliest record of $D$. melanostictus in East Nusa Tenggara is from 2012 (Fig. 1). In the Lesser Sunda islands, D. melanostictus has been found in Mount Rinjani National Park in Lombok [19-20], Mount Tambora National Park in Bima [21], Manupeu Tanadaru National Park in Sumba [22], and in East Timor [23]. The presence of D. melanostictus was also recorded in the western part of Papua in 1995 and 1999 [24].
Table 3. Mean length (SVL) and weight of Duttaphrynus melanostictus in Sape at 15-18 April $2018(\mathrm{~N}=35)$

\begin{tabular}{|c|c|c|c|c|c|c|c|}
\hline \multirow[b]{2}{*}{ Sex } & \multirow[b]{2}{*}{$\mathrm{N}$} & \multicolumn{3}{|c|}{ SVL $(\mathrm{cm})$} & \multicolumn{3}{|c|}{$\mathrm{W}(\mathrm{g})$} \\
\hline & & 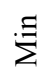 & $\stackrel{\Xi}{\Sigma}^{\not \varpi}$ & $\sum_{\Sigma}^{\tilde{\Xi}}$ & $\dot{g}$ & 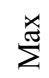 & 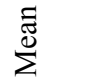 \\
\hline Males & 11 & 6.2 & 9 & $\begin{array}{l}7.21 \\
\pm \\
0.94\end{array}$ & 11 & 76 & $\begin{array}{l}26.20 \\
\pm \\
18.32\end{array}$ \\
\hline Females & 16 & 6 & 10.5 & $\begin{array}{l}7.49 \\
\pm \\
1.38 \\
\end{array}$ & 8 & 80 & $\begin{array}{l}34.70 \\
\pm \\
22.76\end{array}$ \\
\hline Juvenile & 8 & 3 & 5.5 & $\begin{array}{l}4.69 \\
\pm \\
0.88\end{array}$ & 4 & 18 & $\begin{array}{l}6.99 \pm \\
4.52\end{array}$ \\
\hline
\end{tabular}

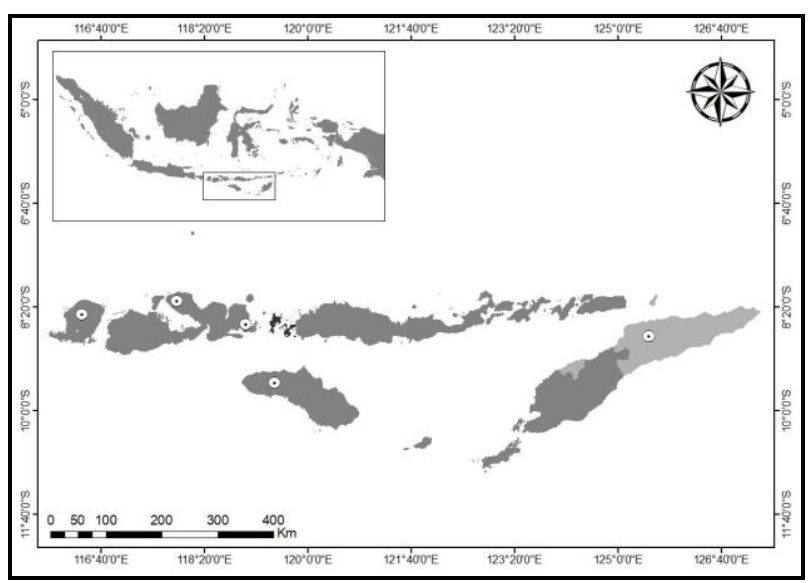

Fig. 1 The distribution of D. melanostictus in Lesser Sunda. Source: MZB and reports from Septian (2016), Syazalli et al. (2006), Himakova (2015), Himakova (2009), and O'Shea et al. (2012)

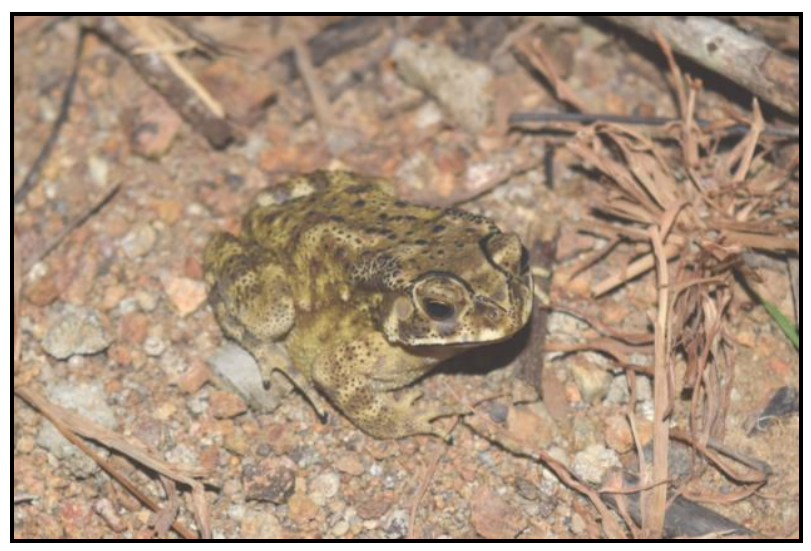

Fig. 2 Duttaphrynus melanostictus in Sape, Sumbawa island

The widespread presence of species such as $F$. cancrivora and $D$. melanostictus usually occurs because of carried accidentally by human and established in the area. The introduction of a species to a location outside its natural distribution does not always result in the successful establishment of this species outside its natural habitat. Based on the ten rules of Williamson \& Fitter [25], the possibility of introduced species becoming invasive species is very small; in other words, it is difficult to detect the negative impacts of introduced species. To estimate the long-term impact of an invasive 
species, there is a need to have information on the habitat suitability of a species, the reaction of local species to the introduced species, and where and how a species will be introduced [26] is a required.

There are many factors that enables non-native species to survive and thrive in a new environment, including suitable climate, the absence of predators, availability of food sources and good adaptability [26]. Both $F$. cancrivora and $D$. melanostictus are able to adapt to harsh environments, especially salinity [27-28]. However, the impact of the establishment of $D$. melanostictus and $F$. cacrivora on local wildlife might vary. There is no report of negative impact from the occurrence of $F$. cancrivora however D. melanostictus is a toad of the family Bufonidae which has a paratoid gland that functions as self-protection from its predators, such as birds, mammals, snakes and crocodiles [29]. Its paratoid gland secretes biogenic amino acids, bufodienolides, alkaloid-steroid and peptide-protein which are toxic to predators [5]. Thus, the toad can cause population decline from a naïve predator in an area that has no other type of poisonous frog. In addition, the toad is a predator that eats various invertebrates [30] including the blind snake, Ramphotyphlops braminus [23]. The Asian toad will compete with native species and might cause the loss of local species. Research conducted by Ujvari et al. [31] on five Komodo blood samples showed 12 amino acid sequences containing the $\mathrm{H} 1-\mathrm{H}$ domain that are identical to varanids from Australia, which are vulnerable to toads' poisoning.

The wide distribution of the Asian toad in Indonesia, especially in the Nusa Tenggara region suggest the possibility that in the future this toad may be found on Flores Island including in the Komodo National Park. This is likely particular because there is no extreme habitat and climate difference between Flores island and other islands that have been introduced by $D$. melanostictus, such as Sumbawa and Sumba islands. Given this, it is surprising that until now there have been no reports of the presence of $D$. melanostictus on Flores Island. The low level of research in the Flores area could be one of the factors for the absence of frog reports in Flores, although this is still to be proven. The Asian common toad might have already been introduced to Flores Island and Komodo National Park, however, the absence of $D$. melanostictus in this area may be due to factors that prevent this species from surviving, although this is not certain.

The establishment of non-native species usually begins with introduction and is followed by the spread of the species, leading to invasions which result in impacts on the local environment and local species [32]. The introduction of a species to a place can occur through various means, but is mainly caused by human mobility [26]. Komodo National Park as a world heritage site is famous as a tourist destination for domestic and international tourists. The increase in mobility of tourist from outside the area into the National Park via boats may be one of the means of the introduction of $D$. melanostictus into the Komodo National Park area. Sape and Labuan Bajo are the gateways of tourist mobility into Komodo National Park, however the traffic is greater from Labuan Bajo compared to Sape. There is a need for awareness among all stakeholders in Komodo National Park, as well as tourism operators from Labuan Bajo and Sape, about the dangers and impacts of $D$. melanostistus on ecosystems.

To prevent the spread of $D$. melanostictus in Komodo National Park, there is a need to continue periodic monitoring of herpetofauna species and educating the community in and around the area about the danger of $D$. melanostictus to the conservation of the Komodo dragon. The lack of information about the species of herpetofauna on the island of Flores and the presence of species not yet discovered in this study but recorded in other studies (such as [16]) shows the importance of regular monitoring. Early detection is important as eradication in the early stages is relatively easier to manage [33]. Measures to prevent the spread of $D$. melanostictus can be done by installing warning boards to enable people to identify the toad and report any suspected occurrences to Komodo National Park officials for any suspected presence. In addition, there is a need to inspect ships that dock in the Komodo National Park area to ensure that they do not accidently bring the species from outside the national Park.

Funding for this research was given by the EAZA through the Komodo Survival Program for UFK. Other generous funding was given to MDK by University of Florence to fund travel to Komodo island. We thank the Komodo National Park office, especially the head of the National Park, Bapak Budhy, and staff of Komodo National Park: Maria Rosdalima Panggur, Boby Darmawan and Danan for their assistance. We thank Deni Purwandana, and Claudio Ciofi for the help and advice during the research. We are grateful for the help of Fitria Suci Ramadani, Mufti, Adam, pak Sidik and teachers of SMK Kelautan Sape for their assistance in the field. Research in the National Park has been granted through the SIMAKSI no. SI. 24/T.17/TU/2/2018.

\section{References}

1. D. Pimentel, L. Lach, R. Zuniga, D. Morrison, BioScience 50(1), 53-65 (2000) DOI: $10.1641 / 0006-$ 3568(2000)050[0053:EAECON]2.3.CO;2

2. D.M. Lodge, S. Williams, H.J. MacIsaac, K.R. Hayes, B. Leung, S. Reichard, R.N. Mack, P.B. Moyle, M. Smith, D.A. Andow, J.T. Carlton, A. McMichael, Ecological Applications 16(6), 20352054 (2006) https://doi.org/10.1890/10510761(2006)016[2035:BIRFUP]2.0.CO;2

3. J.L. Lockwood, M.F. Hoopes, M.P. Marchetti, Invasion Ecology. Massachusetts (Blackwell Malden, US 2007)

4. S.B. Reilly, G.O.U. Wogan, A.L. Stubbs, E. Arida, D.T. Iskandar, J.A. McGuire, Global Chage Biology 23(12), 1-3 (2017) DOI: 10.1111/gcb.13877

5. B.T. Clarke, Biol Rev Camb Philos Soc 72(3), 365379 (1997) DOI: 10.1017/s0006323197005045

6. A.D. Griffiths, J.L. McKay, Wildlife Research 34, 609-615 (2007) DOI: 10.1071/WR07024 
7. G. Church, Herpetologica 16(1),15-21 (1960) https://www.jstor.org/stable/3890315

8. D.R. Frost. Amphibian Species of the world Ver 6.0. (2017)

9. F. Andreone, J.E. Cadle, N. Cox, F. Glaw, R.A. Nussbaum, C.J. Raxworthy, S.N. Stuart, D. Vallan, M. Vences, Conserv. Biol 19, 1790-1802 (2005) DOI: $10.1111 /$ j.1523-1739.2005.00249.x

10. M.D. Kusrini, Panduan Bergambar Identifikasi Amfibi Jawa Barat, (Fakultas Kehutanan IPB, Bogor 2013)

11. T. Setiyati, Parameter demografi dan pola penyebaran spasial rusa timor di Pulau Rinca Taman Nasional Komodo (Institut Pertanian Bogor, Bachelor thesis, Bogor 2008)

12. W.R. Heyer, M.A. Donnelly, R.W. McDiarmid, L.C. Hayek, M.S. Foster, Measuring and Monitoring Biodiversity: Standard Methods for Amphibians, (Smithsonian Institution Press, Washington 1994)

13. P. Uetz, T. Etzold, The EMBL/EBI reptile database. Herpetological Review 27(4), 174-175 (1996)

14. B.V. Ngo, C.D. Ngo, Zoologi Studies 52(12), 1-13 (2013) https://doi.org/10.1186/1810-522X-52-12

15. R.H. MacArthur, E.O. Wilson, The Theory of Island Biogeography, (Princeton University Press, Princeton 1967)

16. W. Auffenberg, Bulletin of the Florida States Museum Biological Sciences 25(2), 40-150 (1980)

17. E.R. Dunn, American Museum Novitates 286, 1-10 (1928)

18. M.M. Islam, N. Kurose, Md.M.R. Khan, T. Nishizawa, M. Kuramoto, M.S. Alam, M. Hasan, N. Kurniawan, M. Nishioka, M. Sumida, Zool Sci 25: 1084-1105 (2008) doi: 10.2108/zsj.25.1084.

19. I.G.N. Septian, Keanekaragaman amphibia (ordo anura) dan preferensi makanan dua spesies Limnonectes (L. kardasani dan L. dammermani) di Taman Nasional Gunung Rinjani Lombok, (Institut Pertanian Bogor, Thesis, Bogor 2016)

20. M. Syazali, A.A. Idrus, G. Hadiprayitno, Proceeding Biology Education Conceference 13(1), 730-735 (2016)
21. [HIMAKOVA IPB] Himpunan Mahasiswa Konservasi Sumberdaya Hutan dan Ekowisata Institut Pertanian Bogor, Panduan Lapang Fauna Taman Nasional Gunung Tambora, (BKSDA NTB, Mataram 2015)

22. [HIMAKOVA IPB] Himpunan Mahasiswa Konservasi Sumberdaya Hutan dan Ekowisata Institut Pertanian Bogor, Laporan Studi Konservasi Lingkungan (SURILI) 2009: Warna-warni Khasanah Budaya dan Hidupan Liar Langit Sumba di Taman Nasional Manupeu Tanadaru, Nusa Tenggara Timur, (Institut Pertanian Bogor, Bogor 2009)

23. M. O'Shea, A. Kathriner, S. Mecke, C. Sanchez, H. Kaiser, Herpetology Notes 6, 467-470 (2013)

24. J.L. Menzies, R.F. Tapilatu, Science in New Guinea 25, 70-73 (2000)

25. M. Williamson, A. Fitter, Ecology 77(6), 1661-1666 (1996) https://doi.org/10.2307/2265769

26. T.A. Crowl, T.O. Crist, R.R. Parmenter, G. Belovsky, A.E. Lugo, Front Ecol Environ 6(5), 238-246 (2008) DOI: 10.1890/070151

27. R. Strahan, Copeia 2, (1957) DOI: 10.16373/j.cnki.ahr. 170083

28. W.A. Dunson, Copeia 1977(2), 375-378 (1977) DOI: $10.2307 / 1443921$

29. K. Awasthi, Biocontrol Backfires 14(22), 46-48 (2006)

30. B. Döring, S. Mecke, M. Kieckbusch, M. O'shea, H. Kaiser, Journal of Natural History 51, 1-17 (2017) DOI: $10.1080 / 00222933.2017 .1293182$

31. B. Ujvari, H.C. Mun, A.D. Conigrave, C. Ciofi, T.Madsen, Pacific Conservation Biology 20(4), 363-365 (2014) DOI: 10.1071/PC140363

32. J.M. Levine, Biological invasions. Current Biology 18, R57-R60 (2008)

33. D. Simberloff, J.L. Martin, P. Genovesi, V. Maris, D.A. Wardle, J. Aronson, F. Courchamp, B. Galil, E. García-Berthou, M. Pascal, P. Pyšek, R. Sousa, E. Tabacchi, M, Trends in Ecology \& Evolution 28, 58-66 (2013) https://doi.org/10.1016/j.tree.2012.07.013 